\title{
MESOTHELIOMA RISK ASSOCIATED WITH ASBESTOS PRODUCTION IN SLOVENIA
}

\author{
Marko VUDRAG ${ }^{1}$, Tatja KOSTNAPFEL RIHTAR ${ }^{1}$, and Miljana VEGNUTI ${ }^{2}$ \\ Institute of Public Health of Ljubljana, Ljubljana ${ }^{1}$, University Clinic of Respiratory and Allergic \\ Diseases, Golnik², Slovenia
}

Received in January 2009

Accepted in October 2009

\begin{abstract}
The aim of this study was to assess malignant mesothelioma morbidity due to exposure to asbestos in a population living in districts Nova Gorica and Tolmin (49,850 people) near the asbestos manufacturing village Anhovo (Slovenia) and to compare it with the entire Slovene population (1,949,750 people). Crude rates per 100,000 people were calculated from the total number of mesotheliomas, and risk assessment in the studied vs. total population was based on 23 years worth of data. Time series data on mesothelioma cases were also processed as a forecast of new cases by 2010 .

The crude incidence of mesothelioma per 100,000 individuals for all of Slovenia was 21.4, while for the Nova Gorica district including the village Anhovo it is 170.2 and for the Tolmin district 60.9. The probability of a mesothelioma case in the studied population was 8.5 times the probability of the same diagnosis in the whole of Slovenia. Over 23 years, $28 \%$ of all mesothelioma cases in Slovenia were diagnosed in the studied population, which makes only $2.5 \%$ of the total Slovene population.

The outbreak of asbestosis and mesothelioma epidemics in the studied population is associated with manufacture of asbestos products in the local factory from 1922 to 1996.
\end{abstract}

KEY WORDS: asbestosis, lung malignancies, mesothelioma, Salonit Anhovo

Asbestos use began about 4,500 years ago. Evidence of its use to strengthen clay pottery goes as far back as 2,500 BC. The use of asbestos is one of the most controversial issues in the minerals industry. Its carcinogenic nature, an overall lack of knowledge about safe exposure thresholds, its widespread use for more than 100 years, and the long latency for the development of lung cancer and mesothelioma are the main subjects of these controversies. The British first raised health concerns in the early part of the $20^{\text {th }}$ century, but it was not until the late 1950 s that a correlation between excess exposure to asbestos fibres and respiratory cancer diseases was established (1).

"Disease caused by asbestos" (2) includes physical, chemical, and carcinogenic effects of asbestos on human health. Asbestosis is a diffuse interstitial lung fibrosis, which was first described in 1907 among British workers in asbestos spinning mills (3). In the 1960s, asbestos alarmed the public with mesothelioma. The first cases were described and confirmed among workers in industries producing or using asbestos (4), but now the first asbestos-caused diseases appeared amongst workers' family members, who had never worked with asbestos at all (5). The workers seem to have brought asbestos home with dust on their clothes.

The latency period from exposure to asbestos to the manifestation of the malignant pleural mesothelioma can be as long as 30 to 40 years (6).

About 670,000 tof asbestos have been imported to Slovenia since 1946. Thousands of workers had been occupationally exposed to asbestos, of whom at least 23,000 in 14 major enterprises in Slovenia (7). The asbestos-cement product manufacturer in the village of 
Anhovo had been using asbestos since 1922 (8). There were three production lines in the Salonit Anhovo plant: cement production, production of asbestoscement pipes, and production of corrugated sheets. The production gradually increased until it reached $25,000 \mathrm{t}$ of asbestos per year, of which chrysotile accounted for more than $98 \%$ and amphiboles up to $2 \%$ (the quantities of amphiboles added depended on the market price, but were a small fraction of total asbestos consumption, from $0.009 \%$ to $2.1 \%$ ) (9). Consumption peaked in the 1970s and 1980s. There are estimates that in these years the factory employed 2,500 workers in average, of whom 600 were directly exposed to asbestos (8). Other authors mention different data and a case control study (9) determined a cohort of 6,714 people employed at Salonit Anhovo between 1946 and 1994, who were directly exposed to asbestos for at least one day.

It is important to know that certain aspects of occupational exposure to asbestos and the associated incidence of lung cancer have been studied quite well in Slovenia, including the amphibole hypothesis and the role of genetic polymorphism in the development of malignant diseases in people occupationally exposed to asbestos in Slovenia (9-11). On the other hand, the impact of asbestos pollution on wider population has not yet been studied.

Our belief that exposure to asbestos was wider than occupational has been gaining ground in scientific circles. This is due to the increasing number of mesothelioma cases not only in the occupationally exposed. The families of the workers who brought fibres home in clothes, hair, etc. were also exposed.

In Slovenia we have a very good cancer registry collecting data over several decades. Among other purposes, this database was also designed to map the accurate geographical distribution of malignant diseases. For the purpose of this study we used the original division of Slovenia into 61 districts (now the country is divided in 210 districts).

The aim of our study was to compare mesothelioma morbidity in populations from districts that provided the workforce for Salonit Anhovo with the population of the entire country.

\section{METHODS}

This study included the population of Anhovo and of the districts of Nova Gorica and Tolmin, as the vast majority of the workforce came from these two administrative units. For easier reading, we shall be referring to this population as the "study population". It includes 49,850 people between 1983 and 2005 . The studied population is about $2.5 \%$ of the country's population. We analysed and compared mesothelioma rates between the studied population and the entire Slovene population relying on the data taken from the national cancer registry database for the period 1983-2005. This period was selected because since 1983 each registered mesothelioma case had been histologically verified.

The calculated crude rate is the number of mesothelioma cases per 100,000 people. According to the WHO, a crude rate is "the number of causespecific events (in our study: mesothelioma cases) over a specified period of time (in our study: 19832005 ) divided by the total population" (12). We used the crude rate instead of the age-standardized rate because we consider the studied and the total Slovene populations similar in demographic variables such as age and sex. The crude rate can safely be used for comparison whenever we expect populations to have similar demographics (13).

However, considering the low incidence of mesothelioma in general population all over the world, we believed that the use of Poisson likelihood may be better in predicting it for population as small as ours (14). Likelihood is the probability of an observed outcome as a function of the number of people (n) living in a particular area. It applies to various phenomena of discrete nature, that is, those that may happen 1,2,3, or more times over a given period of time or in a given area, whenever the probability of the phenomenon happening is constant in time or space. Mesothelioma cases belong to such instances. The crucial assumption here is that events in disjoint subsets are independent of each other. Our study was focused on the incidence of mesothelioma cases as a number of discrete occurrences that took place over a 23-year interval in two given areas, one being the Anhovo vicinity (the studied population) and the other being the whole of Slovenia. If the expected number of occurrences in this interval is 1 , then the probability that there are exactly $k$ occurrences is

$$
f(k ; \lambda)=\frac{\lambda^{k} e^{-\lambda}}{k !},
$$

where $e$ is the base of the natural logarithm $(e=2.71828 \ldots) ; k$ is the number of occurrences of an event - the probability of which is given by the function, and 1 is the expected number of occurrences 
that occur during the given interval.

To calculate the maximum likelihood, we form the log-likelihood function:

$$
\begin{aligned}
& \left.L(\lambda)=\log \prod_{i=1}^{n} f\left(k_{i} \mid \lambda\right)=-n \lambda+\sum_{i=1}^{n} k_{i}\right) \log \lambda- \\
& -\sum_{i=1}^{n} \log \left(k_{i} !\right) .
\end{aligned}
$$

First, we take the derivative of $L$ with respect to 1 and equate it to zero. Solving for 1 yields a stationary point, which, if the second derivative is negative, is the maximum likelihood estimate of 1 .

Poisson probability function basically suggests that the probability of an event is lower in a small community and higher in a large community. Trend calculation procedure was applied to fit and forecast values and residuals for a 23-year time series, using an algorithm that smoothes out irregular components of time series data. A trend line represents the long-term movement in time series data after other components have been accounted for. It tells whether a particular data set has increased or decreased over a period of time. A trend line could simply be presented with a set of data points, but a more proper position and slope is calculated using the regression method. Trend lines are often used to argue that a particular action or event caused observed changes at a point in time.

The data were processed using analytical software IBM SPSS Statistics version 16.0 and $\mathrm{R}$ version 2.7.0 (issued by the R Foundation for Statistical Computing).

\section{RESULTS AND DISCUSSION}

Table 1 shows the total number of mesothelioma diagnoses from 1983 to 2005 and crude rates per 100,000 people in 50 of the 61 original Slovene districts. The eleven excluded districts have had no mesothelioma diagnosis. The total number of mesothelioma cases from the first registry record to 2005 is 404 . Today, the crude incidence per 100,000 people from the districts of Tolmin and Nova Gorica, that were the source of the Anhovo factory workforce, is 231.1 (170.2 for Nova Gorica, including the village of Anhovo, and 60.9 for Tolmin). By contrast, the crude incidence per 100,000 of the total country's population is 21.4, Nova Gorica and Tolmin included.

The first two cases of asbestosis in the Salonit Anhovo factory were confirmed in 1981. This year is considered the beginning of asbestosis and mesothelioma epidemic, which is still going on. Most of the people who had this disease worked in the Salonit Anhovo factory and lived in its surroundings (the studied population).

To make a comparison between the studied vs. entire Slovene population, we calculated relative annual rates with respect to population size. The probability of one mesothelioma case in the studied population turned out to be 8.5 times higher (Table 2) than in the entire Slovene population. Table 2 shows the age distribution of mesothelioma cases and calculations of Poisson likelihood. Poisson distribution shows whether differences in the number

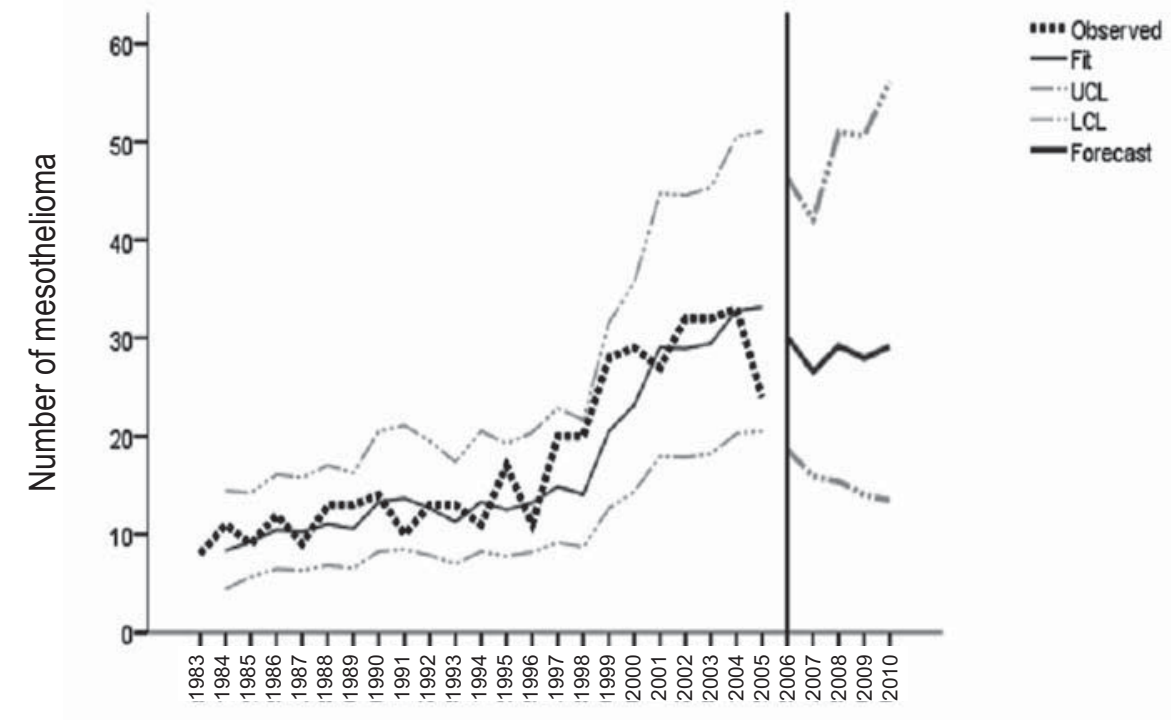

Figure 1 Predicted mesothelioma trends in Slovenia by 2010 
Table 1 Total number of mesothelioma diagnoses in Slovenia from 1983 to 2005 and crude rates per 100,000 people

\begin{tabular}{|c|c|c|}
\hline District & Number of mesothelioma diagnoses & Crude rate per 100,000 people \\
\hline Nova Gorica & 101 & 170.2 \\
\hline Tolmin & 12 & 60.9 \\
\hline Maribor & 66 & 45.1 \\
\hline Piran & 7 & 40.3 \\
\hline Tržič & 5 & 32.6 \\
\hline Slovenska Bistrica & 10 & 28.8 \\
\hline Sevnica & 5 & 27.7 \\
\hline Črnomelj & 5 & 26.7 \\
\hline Ormož & 4 & 22.7 \\
\hline Koper & 11 & 21.9 \\
\hline Vrhnika & 4 & 17.8 \\
\hline Krško & 5 & 17.7 \\
\hline Ljubljana & 58 & 17.6 \\
\hline Ptuj & 12 & 17.3 \\
\hline Ljutomer & 3 & 16.4 \\
\hline Lendava & 4 & 16.3 \\
\hline Šmarje pri Jelšah & 5 & 15.6 \\
\hline Šentjur & 3 & 15.1 \\
\hline Gornja Radgona & 3 & 14.5 \\
\hline Ilirska Bistrica & 2 & 14.1 \\
\hline Grosuplje & 5 & 13.9 \\
\hline Domžale & 7 & 13.2 \\
\hline Izola & 2 & 12.9 \\
\hline Žalec & 5 & 12.3 \\
\hline Mozirje & 2 & 12.1 \\
\hline Radlje & 2 & 12.0 \\
\hline Idrija & 2 & 11.8 \\
\hline Dravograd & 1 & 11.3 \\
\hline Trbovlje & 2 & 11.2 \\
\hline Celje & 7 & 11.0 \\
\hline Laško & 2 & 10.9 \\
\hline Murska Sobota & 6 & 10.3 \\
\hline Hrastnik & 1 & 9.7 \\
\hline Novo mesto & 6 & 9.6 \\
\hline Jesenice & 3 & 9.5 \\
\hline Slovenj Gradec & 2 & 9.2 \\
\hline Velenje & 4 & 8.7 \\
\hline Sežana & 2 & 8.3 \\
\hline Logatec & 1 & 8.1 \\
\hline Kamnik & 2 & 6.1 \\
\hline Zagorje & 1 & 5.8 \\
\hline Radovljica & 2 & 5.7 \\
\hline Kočevje & 1 & 5.5 \\
\hline Kranj & 4 & 5.2 \\
\hline Litija & 1 & 5.0 \\
\hline Škofja Loka & 2 & 4.8 \\
\hline Postojna & 1 & 4.7 \\
\hline Slo. Konjice & 1 & 4.3 \\
\hline Ajdovščina & 1 & 4.2 \\
\hline Ravne & 1 & 3.8 \\
\hline Total & 404 & 21.4 \\
\hline
\end{tabular}


Table 2 Comparison of mesothelioma cases (N) in Slovenia from 1983 to 2005 by age groups; annual averages, Poisson likelihood, and probability of one event

\begin{tabular}{lcc}
\hline $\begin{array}{l}\text { Age groups / } \\
\text { year }\end{array}$ & Studied population & Total Slovene population \\
\hline 20 to 24 & 0 & 3 \\
25 to 29 & 0 & 1 \\
30 to 34 & 2 & 0 \\
35 to 39 & 2 & 5 \\
40 to 44 & 3 & 7 \\
45 to 49 & 5 & 30 \\
50 to 54 & 18 & 27 \\
55 to 59 & 13 & 41 \\
60 to 64 & 18 & 56 \\
65 to 69 & 23 & 42 \\
70 to 74 & 14 & 22 \\
over 75 & 15 & 57 \\
\hline N & 113 & 291 \\
\hline Annual average & 4.91 & 12.65 \\
Per 100,000 inhabitants & 6.08 & 0.66 \\
Poisson likelihood & 0.00235 & 0.18377577 \\
Probability of 1 event & 0.00121292 & 0.000143 \\
\hline
\end{tabular}

of occurrences between populations are accidental or a result of some pattern. According to the law of rare occurrences, both the studied and total Slovene populations have a small probability of mesothelioma occurrence.

Cumulative data on age distribution of mesothelioma cases give the impression that most cases were diagnosed at an advanced age (Table 2).

Because the annual mesothelioma incidence was small and irregular, the forecast from 2006 to 2010 is also uneven (Figure 1). For 2006 the expected incidence is 30 cases (95\% CI: 19; 46), for 2007 27 cases (95\% CI: 16; 42), for 200829 cases $(95 \%$ CI: 15 ; 51), for 200928 cases (95\% CI: $14 ; 51)$, and for 201029 cases (95\% CI: 13; 56). However, the precision of these predictions is low due to wide confidence intervals, which in turn are mainly due to irregular occurrences.

"Mesothelioma, a Twentieth-Century Tumour" (15) is an extremely rare malignant tumour (four to five cases per $1,000,000$ persons per year) that develops in the pleura, pericardium, and peritoneum. Some authors claim that over $90 \%$ of all mesothelioma cases are caused by asbestos $(16,17)$. Others claim that exposure to asbestos is in fact the only cause of mesothelioma (18). The epidemics of malignant diseases caused by asbestos are expected to peak in the next few decades. The peak of asbestos diseases in Slovenia is expected for after 2020. This is in agreement with the data from developed countries (Finland, UK, Germany, Norway, and Sweden), which have well-developed systems of diagnosis, identification, registration, and compensation $(19,20)$. These data show an increasing trend in the incidence of cancers (malignancies) associated with exposure to asbestos. In Slovenia, the most widespread use was between 1975 and 1985 (7).

The course of the disease is very fast; the tumour metastasises and the patient dies within a year. Undoubtedly, asbestos is also a risk factor for populations living around asbestos plants or mines (21). Most reports of mesothelioma associated with non-occupational exposure come from these areas (22).

It is known that in Slovenia asbestos was most extensively used in the Salonit Anhovo factory, while protective measures were very poor (7). The estimated incidence of asbestoses (pneumoconioses) in Slovenia is uncertain, because methods of disease verification as occupational are dubious and involve legal and insurance ramifications. In contrast, the number of registered mesotheliomas in Slovenia for the years 1983 to 2005 is exact. This is because the Cancer Registry of Slovenia always presents the final data on the cancer with a two or three-year lag to allow enough time to verify the data. However, it is reasonable to assume that the national cancer registry has failed to record some cases; patients with confirmed 
mesothelioma may have died of another cause or may have moved away (seasonal workers, migration), as the workforce came from other countries as well.

Figure 1 shows the increasing trend of mesothelioma incidence in Slovenia. A similar trend has been observed in Croatia. Between 1994 and 2000, the number of newly diagnosed mesothelioma increased, reaching a peak of 20 a year (23). As we said earlier, the mesothelioma epidemic in Slovenia is expected to peak in the following 10 to 15 years (Figure 1).

Table 2 shows that younger age groups from the studied population have a lower mesothelioma incidence than the same age groups in the whole of Slovenia. This may be due to factors other than asbestos, which have a role in the pathogenesis of mesothelioma. In fact, it is usual that the incidence of a disease is greater in a bigger population. Furthermore, it can be expected that the epidemic of mesothelioma in the studied population will occur when the people who belong to the young age groups reach older age, because mesothelioma latency after exposure to asbestos is between 30 and 50 years.

Because of the problems caused by asbestos, the Ministry of Health of the Republic of Slovenia proposed the "Decree prohibiting and restricting production, trade in and use of asbestos and asbestos products" in accordance with European legislation (24). The Decree was passed in 1998, and asbestos ban has been fully enforced since 1 January 2003, but the provisions do not apply to asbestos already in use (24).

The remaining asbestos and asbestos products should be removed from everyday use with as much care and as soon as possible. Disposal (immobilisation) of asbestos waste should be planned and monitored, as asbestos presents a health hazard when moved, such as with roofing removal. This is why in 2005, an international group of WHO experts created guidelines and a list of twelve substances that can replace asbestos fibres (25).

Persons occupationally exposed to asbestos should undergo regular and focused medical examination for the rest of their lives. This includes monitoring the retired and former asbestos workers. Furthermore, a record should be maintained of health problems and death associated with asbestos exposure.

\section{CONCLUSION}

Our findings suggest that the mesothelioma epidemics in the studied population is associated with exposure to asbestos during the years of its use in the Salonit Anhovo factory.

Most of the mesothelioma cases were the consequence of a lack of knowledge, blunder regarding asbestos, and especially of insufficient protection of workers who handled asbestos.

Our study does not distinguish between the occupationally exposed and non-occupationally exposed population, and this limits its merits. However, the high incidence of mesothelioma in the studied population (occupationally exposed and non-occupationally exposed) calls for a particular care to be exerted in the final disposal of asbestos and underlines the importance of close monitoring of population at risk.

\section{Acknoweldgements}

The aggregated data for all mesothelioma cases in the last two decades are kept in the Cancer Registry of Slovenia database. We owe special thanks to the director Maja Primic Žakelj, Ph.D. and Vesna Zadnik, Ph.D. from the Cancer Registry for their help and support in finding and critically assessing the data.

Sincere thanks go to Metka Filipič, Ph.D. from the National Institute of Biology for her critical review and most helpful professional suggestions.

\section{REFERENCES}

1. Virta RL. Worldwide asbestos supply and consumption trends from 1900 to 2003. Supersedes Open-File Report 03-083 [displayed 14 July 2009]. Available at http://pubs. usgs.gov/circ/2006/1298/c1298.pdf.

2. Wagner JC, Pooley FD. Mineral fibres and mesothelioma. Thorax 1986;41:161-6.

3. McDonald AD. Mesotheliomas registries in indentifying asbestos hazards. Ann NY Acad Sci 1979;330:441-54.

4. Wagner JC, Sleggs CA, Marchand P. Diffuse pleural mesothelioma and asbestos exposure in the North Western Cape Province. Br J Ind Med 1960;17(4):260-71.

5. Oern S, Odden S, Osnes M. Familiaer opphopning av asbestrelatert sykdom [Familial clustering of asbestos - related disease, in Norwegian]. Tidsskr Nor Laegeforen 1991;111:1099-101.

6. International Agency for Research on Cancer (IARC). IARC Monographs on the evaluation of the carcinogenic risk of chemicals to man. Asbestos. Vol 14. Geneva: IARC; 1977.

7. Dodič Fikfak M, Šešok J. Nacionalne smernice za azbest. Zaključno poročilo projekta [National guidelines for asbestos. Final report, in Slovene]. Inštitut za varovanje zdravja RS [Public Health Institute of Slovenia - in Slovene]. Ljubljana, 1999.

8. Anonymus. Salonit Anhovo - petdesetletnik [Salonit Anhovo - 50 Years, in Slovene]. Nova Gorica: ČZP Soča; 1971. 
9. Dodič-Fikfak M, Kriebel D, Quinn MM, Eisen EA, Wegman DH. A case control study of lung cancer and exposure to chrysotile and amphibole at a Slovenian asbestos-cement plant. Ann Occup Hyg 2007;51:261-8.

10. Dodič-Fikfak M. The amphibole hypothesis - a nested casecontrol study of lung cancer and exposure to chrysotile and amphiboles. Arh Hig Rada Toksikol 2003;54:169-76.

11. Franko A, Dolžan V, Arnerić N, Dodič-Fikfak M. Asbestosis and catalase genetic polymorphism. Arh Hig Rada Toksikol 2008;59:233-40.

12. World Health Organization. WHO Global Info Base: Crude vs. Standardized Rates [displayed 5 February 2010]. Available at https://apps.who.int/infobase/help. aspx?helpid $=43$.

13. Lee ET. Statistical Methods for Survival Data Anaysis. $2^{\text {nd }}$ ed. New York (NY): John Wiley \& Sons; 1992. p. 95-6.

14. Rice JA. Mathematical Statistics and Data Analysis. $3^{\text {rd }}$ ed. Belmont (CA): Thomson/Brooks/Cole; 2007.

15. Last JM, Wallace RB, editors. Maxcy-Rosenau-Last Public Health and Preventive Medicine. $13^{\text {th }}$ ed. Norwalk (USA): Appleton \& Lange; 1992.

16. Doll R, Peto J. Asbestos: effects on health of exposure to asbestos. London: Health and Safety Commission; 1985.

17. Sever Jurca D. Ovrednotenje bioloških učinkov azbesta na delavce in prebivalce $\mathrm{v}$ soseski azbestno - cementne industrije. Doktorska disertacija. [Evaluation of biological effects of asbestos on workers and population in the vicinity of asbestos-cement industry, in Slovene]. [PhD thesis]. Ljubljana: Faculty of Medicine Ljubljana; 1983.

18. Driscoll T, Nelson DI, Steenland K, Leigh J, ConchaBarrientos M, Fingerhut M, Prüss-Ustün A. The global burden of diseases due to occupational carcinogens. Am J Ind Med 2005;48:419-31.
19. Directive 2003/18/EC of the European Parliament and of the Council of 27 March 2003 amending Council Directive $83 / 477 / \mathrm{EEC}$ on the protection of workers from the risks related to exposure to asbestos at work. OJ L 2003;(97):4852.

20. Gee D, Greenberg M. Asbestos: from 'magic' to malevolent mineral. In: Harremoes P, Gee D, MacGarvin M, Stirling A, Keys J, Wynne B, Guedes Vaz S, editors. The precautionary principle in the $20^{\text {th }}$ century. Late lessons from early warnings. London: Earthscan Publications; 2002. p. 49-63.

21. Morrow PE. Possible mechanisms to explain dust overloading of the lungs. Fundam Appl Toxicol 1988;10:369-84

22. International Agency for Research on Cancer (IARC). IARC Monographs on the Evaluation of Carcinogenic Risks to Humans. Overall Evaluation of Carcinogenicity: An updating of IARC Monographs. Vol 1 to 42. Supplement 7 [displayed 14 July 2009]. Available at http://monographs.iarc.fr/ENG/ Monographs/suppl7/suppl7.pdf.

23. Cvitanović S, Znaor L, Konsa T, Ivančević Ž, Perić I, Erceg M, Vujović M, Vuković J, Beg-Zec Z. Malignant and nonmalignant asbestos-related pleural and lung disease: 10-year follow-up study. CMJ 2003;44:618-25.

24. Uredba o prepovedih in omejitvah pri proizvodnji in uporabi azbesta in azbestnih izdelkov [Decree prohibiting and restricting production, trade in and use of asbestos and asbestos products, in Slovene]. Uradni list RS Official gazzette RS 20/1998.

25. World Health Organization (WHO). Summary Consensus Report of WHO Workshop on Mechanisms of Fibre Carcinogenesis and Assessment of Chrysotile Asbestos Substitutes; 8-12 Nov 2005. Lyon, France [displayed 14 July 2009]. Available at http://who.int/ipcs/publications/ new_issues/summary_report.pdf. 


\section{Izvleček}

\section{ZDRAVSTVENI PROBLEMI ZARADI UPORABE AZBESTA V SLOVENIJI}

Glavni cilj raziskave je bil oceniti obolevnost za malignim mezoteliomom zaradi izpostavljenosti azbestu pri populaciji iz okolice Anhovega v dveh upravnih enotah (Nova Gorica in Tolmin), t. j. pri opazovani populaciji v primerjavi s populacijo Slovenije.

Analizirani so bili statistični zdravstveni podatki za opazovano populacijo (49.850 prebivalcev) v primerjavi s populacijo Slovenije (1.949.750 prebivalcev). Grobe incidenčne stopnje na povprečno število prebivalcev so bile izračunane iz skupnega števila mezoteliomov, verjetnosti bolezni v opazovani populaciji in v preostanku države pa so bile izračunane s Poissonovim verjetnostnim računom na podlagi podatkov za 23 let. Časovne serije podatkov o primerih mezotelioma so bile obdelane kot napoved za število novih primerov do leta 2010.

Groba incidenca mezotelioma na 100.000 prebivalcev za Slovenijo znaša 21,4, za opazovano populacijo 170,2 (območje Nove Gorice vključno z Anhovim) in 60,9 (območje Tolmina). Verjetnost za pojavnost mezotelioma v opazovani populaciji je 8,5 -krat večja kot verjetnost za enako diagnozo drugje v Sloveniji. Napovedano je, da se bo v 23-letnem obdobju $28 \%$ vseh primerov mezotelioma pojavilo v opazovani populaciji, ki predstavlja 2,5\% skupne slovenske populacije.

Do izbruha epidemije azbestoze in mezotelioma $v$ opazovani populaciji je prišlo zaradi učinkov proizvodnje azbestnih izdelkov v lokalni tovarni med letoma 1922 in 1996. Za ljudi, ki so bili poklicno izpostavljeni azbestu, bo potrebno doživljenjsko zdravniško pregledovanje.

KLJUČNE BESEDE: azbestoza, mezoteliom, pljučni malignomi, Salonit Anhovo

\section{CORRESPONDING AUTHOR:}

Marko Vudrag Institute of Public Health of Ljubljana

Zaloška 29, SI-1000 Ljubljana

E-mail: marko.vudrag@zzv-lj.si 